\title{
Hand-Rearing and Care of a Group of Roe-Deer
}

\author{
Simona KOSSAK
}

\begin{abstract}
Kossak S., 1981: Hand-rearing and care of a group of roe-deer. Acta theriol., 26, 11: 207-218 [With 4 Tables].

A description is given of methods and course of hand-rearing a group of roe-deer, Capreolus capreolus (Linnaeus, 1758). The purpose of the study was to obtain a social group of roe-deer which would differ from their wild fellows only in respect of the human element having been incorporated into its composition. In order to achieve the formation of a social bond between keeper and roe-deer it was necessary: (a) to obtain the animals at an early age for rearing, (b) for the keeper actively to participate in operations of a social nature (with the exception of play among fawns). In order to provide complete satisfaction of all the animals' requirements they were allocated 21.34 ha of wooded land with tree stands varying in age. The maximum number of roe-deer in this area was six. The advantages and disadvantages of the methods of dealing with the group of roe-deer are discussed and their suitability for scientific studies assessed.

[Forest Res, Inst., Section of Nature Protection, 17-230 Białowieża, Poland].
\end{abstract}

\section{INTRODUCTION}

One of the conditions for defining the role of wild herbivorous animals in the ecosystem is to obtain a good knowledge of their behaviour. The importance of this problem is shown by the extremely large number of publications in this field which appear every year. Studies on behaviour are usually carried out by means of two methods: (1) by observations of wild animals living in freedom and (2) making use of tame animals. The method of observations of wild animals is widely used, particularly in areas with good visibility (steppes, savannah, tundra, hill slopes), in which large herds live or in cases in which the animals are not timid. Observations are made from a vehicle, or while walking, of the behaviour of all animals or selected individuals within the field of vision. The use for such studies of tame animals is particularly suitable in the case of timid species living in small groups, inhabiting densely vegetated areas or those difficult of access. Tests and observations of tame animals are usually carried out in small enclosures in which the animals are dependent on human care. They are less often kept in large enclosed areas 
which meet all the living requirements of the given species. The intermediate method is periodical release of experimental animals into open areas. The method most rarely used is to set tame, marked animals free.

Despite the general opinion held by some research workers (Bergerund \& Nolan, 1970; Nagy, 1974) that results obtained using tame animals may be interpolated to wild animals, this opinion cannot be accepted without reservation. For example, the food preferences of the species are not fully revealed if the animals used for the studies are fed on fodder supplied by man, and are only periodically taken out to natural pastures. The same applies to a large number of ways of behaviour which can be put into effect only in given conditions natural to the species.

The enormous value of information obtained from animals free of stress caused by fear of man cannot however be questioned, and consequently an attempt was made at hand-rearing a group of roe-deer (Capreolus capreolus Linnaeus, 1758) which would differ from their wild fellows only by reason of the fact that man entered into the social composition of the group.

\section{HAND-REARING ROE-DEER}

A total of 7 fawns of both sexes were used for the studies (five in 1976 and two in 1978). The fawns were obtained in the wild state (three males and two females) and from zoological gardens (one female fawn and one male). All were in good health. Two of the male fawns were known to be siblings. The fawns' age at the time they were obtained was from several hours to three days.

The fawns were reared on full cow's milk and powdered milk processed for infants. Five fawns were given cow's milk for the first 3 months, later replaced by powdered milk, and two fawns were fed on mlk prepared from powder for the whole of the rearing period. The chief difficulty in preparing substitute food for fawns lies in the differences in the composition of cow's milk and the milk of does (Table 1), considerable discrepancies being encountered on this subject in literature. Raesfeld (1960) and Tschiderer (1973) state that doe's milk contans far smaller amounts of fat than that of cows, and that fawns, particularly during the first few days of life, are affected by the amount of fat. Nevertheless, as Drescher-Kaden \& Schulz (1973) consider, diluting cov's milk with water as recommended by some authors is not recommended. If it is assumed that in order to achieve increase in body weight of $100 \mathrm{~g} /$ day a fawn must receive approx. $45 \mathrm{~g}$ of protein, daily $\mathrm{m} / \mathrm{k}$ requirements would be about 2 litres of cow's milk diluted with water 
in parts of $1: 1$. This amount, particularly during the first months of the fawn's life, is too great. As shown by studies, the composition of the milk of other species of wild ungulates is very variable and depends on the individual, lactation curve and amount of milk produced (Tschiderer, 1973). It may, however, be concluded that there is usually a high fat content in the milk, far higher than in the milk of domestic cows (cow approx. $3.5 \%$, but reindeer $-19.7 \%$, elk $-9 \%$, mouflon -9.9 to $13.6 \%$, red deer - from 9.2 to $19.7 \%$ (after Drescher-Kaden \& Schulz, 1973). In view of the foregoing it was decided to use milk substitute

Table 1

Comparison of the composition of roe-deer milk and of milk used for rearing the fawns.

\begin{tabular}{|c|c|c|c|c|c|}
\hline $\begin{array}{l}\text { Species } \\
\text { and reference }\end{array}$ & $\begin{array}{c}\text { Water, } \\
\% \%\end{array}$ & $\begin{array}{c}\text { Protein, } \\
\% \%\end{array}$ & Fat, & $\begin{array}{c}\text { Lactose, } \\
\% \%\end{array}$ & Ash, \\
\hline $\begin{array}{l}\text { Roe-deer } \\
\text { Pinter. } 1963 \text { (after }\end{array}$ & & & & & \\
\hline $\begin{array}{l}\text { Drescher-Kaden } \\
\text { \& Schulz, 1973) } \\
\text { Raesfeld, 1956 (after }\end{array}$ & 79.6 & 8.8 & 6.7 & 3.8 & 1.1 \\
\hline $\begin{array}{c}\text { Raesfeld, } 1956 \text { (after } \\
\text { Drescher-Kaden }\end{array}$ & & & & & \\
\hline $\begin{array}{l}\text { \& Schulz, 1973) } \\
\text { Domestic cow }\end{array}$ & 88.0 & 3.8 & 1.4 & 4.5 & 1.1 \\
\hline $\begin{array}{l}\text { Full-cream milk } \\
\text { (Pierieldik et al., 1975) } \\
\text { Powdered milk (for bab }\end{array}$ & 87.6 & 3.3 & 3.7 & 4.7 & 0.7 \\
\hline diluted with water & 82.0 & 5.0 & 4.7 & 7.2 & 1.1 \\
\hline
\end{tabular}

containing approx. $4.7 \%$ fat and approx. $5 \%$ protein. The fawns were simultaneously given a considerable amount of medicinal carbon to counteract any possible digestive disturbances.

The fawns were not given any other nutrients apart from milk, as they had access to natural plant food from the first day of the rearing experiment. The first cropping of plants was recorded about the fifth day of their lives, and at the age of 10-15 days they fed on 14 species of herb layer plants and ligneous plants (Kossak, 1980), which provided them with the nutrient substances they required. As from the first day of the experiment the fawns were observed to consume sand and soil. This is a normal phenomenon in deer (Bubenik, 1965; Espmark, 1969), and presumably serves to activate the alimentary tract and to introduce into the organism the appropriate bacteria required for digestion.

For the first 24 days the fawns were fed ad libitum ( 4 to 9 times per day). As from the 25 th day they were fed three times a day, and as from the 148th day twice daily (Table 4). Observations of wild dear show that as from the 2nd-4th week of life fawns feed 9-11 times a day, after which the number of times they suck milk decreases to 3-7 times a day (Bubenik, 1965; Espmark, 1969). 
Up to the 171st day of rearing the amount of milk supplied each time depended solely on the fawn's appetite, considerable differences occurring in the milk requirements of animals of the same age (Table 2). As from the $172 \mathrm{nd}$ day of rearing milk supply was limited to $1000 \mathrm{ml}$ per day. As does can be seen suckling their fawns in the wild state in the late autumn and even winter, the fawns were supplied with milk until they cxhibited a distinct reduction in the interest they took in this form of food. The total length of the rearing time was from 162 to 194 days,

Table 2

Amounts of milk given to fawns during hand-rearing.

\begin{tabular}{ccc}
$\begin{array}{c}\text { Age of fawns } \\
\text { in days }\end{array}$ & $\begin{array}{c}\text { Number of feeds } \\
\text { per } 24 \text { hours }\end{array}$ & $\mathrm{ml} / 24$ hours/fawn \\
\hline $1-15$ & $4-9$ & $40-1000$ \\
$16-24$ & $5-7$ & $610-1300$ \\
$25-33$ & 3 & $120-1230$ \\
$34-147$ & 3 & $530-1800$ \\
$148-171$ & 2 & $550-1000$ \\
$172-194$ & 2 & 1000 \\
\hline
\end{tabular}

during which time the fawns consumed from 128 to 184 litres of milk. This quantity is similar to the amounts given by other authors. Tschiderer (1973) states that one fawn under hand-rearing conditions consumes approx $3 / 4$ litre and considers that this amount is similar to the doe's milk production (a tame doe milked 3 times a day over a period of 5 weeks gave $750 \mathrm{ml} / 24$ hours; Hecht \& Rieck, 1956, after Bubenik, 1965).

The fawns' development was checked by measuring body weight up to the 30th day of hand-rearing. On account of the stress to which older fawns were exposed during weighing, checks were kept later on by measuring the body height of certain of these animals. Fawns taken for hand-rearing weighed from $0.98 \mathrm{~kg}$ to $1.84 \mathrm{~kg}$ on the initial day (in a wild state the average weight of a newborn fawn is approx $1.4 \mathrm{~kg}$ (Raesfeld, 1960). The mean increase in weight per 24 hours was $88 \mathrm{~g}$ (Raesfeld, $1960-70 \mathrm{~g}$ ). Between the 16th and 20th day the fawns had increased $100 \%$ in weight, and between the 26 th and 20 th day of hand-rearing by a further $100 \%$ in relation to the initial weight. Body weight was doubled between the 100th and 130th day of life.

The above justifies the conclusion that the individual development of fawns during the hand-rearing period was normal and did not differ from the normal course. 


\section{THE LIVING CONDITIONS OF HAND-REARED ROE-DEER}

One of the conditions enabling these animals fully to satisfy their psychophysical life requirements is the creation of an appropriate habitat in which they can live, and consequently particular emphasis was placed on correct design and management of rearing enclosures.

The roe-deer spent the first 6 months of their life in an enclosure measuring $0.84 \mathrm{ha}$, situated in a mixed forest habitat. The enclosure included 0.67 ha of a young tree plantation of varying age and 0.17 ha of fallow ground. The measuremenes of the enclosure for the fawns were determined chiefly by rearing requirements. It was considered that the enclosed area would provide the fawns with a sufficient food supply for a period of 6 months. The fact that the tree plantation varied in age made it possible for the animals to hide in it and the fallow land gave them the opportunity to emerge into an open sunny area, while the relatively small size of the enclosure made work with the animals easier.

After the hand-rearing period the roe-deer were released permanently into an enclosure covering 21.34 ha of wooded land. This enclosure included 4.14 ha of cultivated land, 10.10 of tree plantation and 8.10 ha of an old mixed forest stand.

Under natural conditions the roe-deer's home range, depending on the density of these animals and food conditions, is from 8 to 150 ha, most often from 10 to 20 ha (Bubenik, 1959; Hennig, 1962 a, b; Szczerbiński, 1967; Velentincic, 1975). It was therefore considered that in the first place the size of the enclosure provided the roe-deer with a suitable food supply over the whole of the year, and in the second place enabled them to "organize" the area, i.e. to establish transit paths, feeding places, resting places etc. In order to eliminate stress due to overcrowding, while preventing the individuals from emigrating, numbers were limited to 6 animals. A group of this size is similar to that encountered under natural conditions in wooded areas (Kurt, 1968a, b). In order to adapt the area to the animals' requirements 3 drinking places were arranged and 2 fodder containers set up.

\section{FORMATION OF SOCIAL TIE BETWEEN THE ROE-DEER AND THEIR KEEPER}

A condition for full acceptance of a human by the group of roe-deer is:

A. Obtaining roe-deer early for hand-rearing. The roe-deer is one of the species which exhibit the phenomenon of imprinting. During the first two days of life the fawns' capacity for distinguishing the mother 
is slight, and the tie between the mother deer and its young is gradually formed during the first few days after birth. In fawns from 2-4 weeks old this process is completely finished and the animals by then will not accept any changes in the mother (Bubenik, 1965; Kurt, 1968b; Espmark, 1969). Thus the first and absolutely essential condition for completely taming roe-deer by their keeper is to begin rearing the fawns when only a few hours to a few days old, regardless of whether they are obtained from wild or tame mothers (Nagy, 1974).

The age of the fawns at the time they were taken for hand-rearing was from several hours to three days, and thus the phenomenon of imprinting took place completely and normally (Table 3). Imprinting applies also to formation of a tie between siblings, and thus the maximum period for co-opting fawns to the group was 20 days and was completely successful.

B. Active participation of the keeper in operations of a social character. Among the most important elements in the behaviour of participants in formation of the "maternal families" among roe-deer is care of the young animals. For half an hour after birth the fawn is constantly licked by the mother and exhibits signs of waiting for such care. During the first week of life the young animals are not capable of looking after themselves and the mother carries out all such activities (Espmark, 1969). It may be concluded that such behaviour is intended not only to keep the fawns clean, but takes place shortly before the fawns drink and is often applied to the anal parts, thus rousing appetence for sucking. At the same time by means of smell they acquaint the young animals with the mother's individual smell (Bubenik, 1965). During the first month these operations are entirely one-sided - the mother cares tor her young, but during the second month they take on a reciprocal character (Espmark, 1969).

Bearing the foregoing in mind, one and the same person only looked after the fawns. In order to facilitate formation of the mother-offspring relation with the fawns, food was given from a bottle held in the hand, with simultaneous vocal content. Before and after feeding the animals' anal region was massaged using paper tissue moistened with warm water. The reaction of the fawns to this operation was immediate excretion of the faeces and urine and increased desire to drink. The fawns exhibied a considerable degree of individuality in the course of the tamng process, nevertheless within about 14 days all of them considered the keeper as the mother (Table 3). By this time the majority of the favns actively participated in contacts strengthening the social tie within the group and with the keeper (reciprocal smelling, nuzzling and lickng head and neck). On completion of bottle-feeding (at the age of approx. 
6 months) these contacts had become a constant element of the animal's behaviour.

A different type of social behaviour consists in play, which begins to take place during the first month of the fawns' life. Fawns deprived of their siblings play with the mother (Bubenik, 1965). Espmark (1969) distinguished 6 types of play: sexual, fighting, chasing, solitary running, jumping and capering, solitary exploring expeditions. Play by fawns generally speaking - forms the preliminary to the aggressive behaviour of adult roe-deer. In order to avoid forming such types of behaviour

Table 3

Ontogenesis of imprinting by a human instead of the mother deer in hand-reared fawns.

\begin{tabular}{|c|c|}
\hline $\begin{array}{c}\text { Number of days } \\
\text { spent with } \\
\text { keeper }\end{array}$ & Elements of behaviour \\
\hline $\begin{array}{c}5-11 \\
6-14 \\
7-14 \\
12\end{array}$ & $\begin{array}{l}\text { Timidity, inability to suck from a bottle, frequent undi- } \\
\text { rected sound signals, failure to connect the keeper with } \\
\text { food. } \\
\text { Acquiring the ability to suck from a teat, attempts at } \\
\text { following the keeper, favourable reaction and anticipation } \\
\text { of hygienic care, beginning to connect the keeper with } \\
\text { food. } \\
\text { Running out at sight or sound from a distance of about } \\
6 \text { metres, checking to see if the keeper was present, } \\
\text { searching combined with calling signals directed to the } \\
\text { keeper. } \\
\text { Active participation in touch contacts, in case of alarm } \\
\text { seeking protection from the keeper, unwillingness to be left } \\
\text { alone without the keeper. } \\
\text { Accompanying the keeper in his walk. } \\
\text { Distinguishing the keeper from among a group of stran- } \\
\text { gers, absence of fear of strangers. } \\
\text { Fear of strangers, following after the keeper's voice from } \\
\text { a distance of over } 50 \text { metres. } \\
\text { Calling signals intended solely to communicate with the } \\
\text { keeper and the remainder of the group. }\end{array}$ \\
\hline
\end{tabular}

towards the keeper the latter took no part in such play. At the end of the first year of life only one of the four adult males reared exhibited considerable aggressiveness towards humans. This increased in subsequent years to a pathological condition, and consequently it was removed from the group during the fourth year of life.

Under natural conditions the "maternal families" exhibit a stable social system for 10 months, which next breaks down, leaving the animals only in loose social and spatial contact (Kurt, 1968b). In the studies described, both the frequent periods, often of many hours, spent with the roe-deer and elimination of the possibility of the animals' emigration from the enclosed area, made it possible to prolong this period to two years. In 
later years the social tie greatly slackened in the case of roe-deer rearing young and of males during the rutting period. It was possible to renew contact from autumn to spring, but in this case it consisted chiefly in the animals tolerating the presence of the keeper in their immediate vicinity.

In order to document the appurtenance of man to the social group analysis was made of selected elements of the animals' behaviour which were clearly of an interactional character: (1) Contact by touch voluntary approach by a roe-deer combined with waiting for touch or its initiation. (2) "Following" - the roe-deer got up from a lying position or ran after and accompanied the keeper for a walk over a considerable distance. (3) Escape - running away for a considerable distance from another animal or from the keeper.

Table 4

Frequency of appearance of selected elements of the roe-deers' social behaviour in relation to other members of the group and to the keeper.

\begin{tabular}{|c|c|c|c|c|c|c|c|c|c|}
\hline \multicolumn{6}{|c|}{$\begin{array}{l}\text { Age: } 14 \text { days }-6 \text { months } \\
\text { (on basis of } 91 \text { hours } 15 \text { min. } \\
\text { observations from } 102 \\
\text { observation periods) }\end{array}$} & \multicolumn{4}{|c|}{$\begin{array}{c}\text { Age: } 7-15 \text { months } \\
\text { (on basis of } 71 \text { hours } 55 \mathrm{~min} \\
\text { observations from } 91 \\
\text { observation periods) }\end{array}$} \\
\hline \multirow{2}{*}{$\begin{array}{c}\text { Touch } \\
1\end{array}$} & \multirow{2}{*}{$\begin{array}{c}\text { contact } \\
2\end{array}$} & \multicolumn{2}{|c|}{ Following } & \multicolumn{2}{|c|}{ Touch contact } & \multicolumn{2}{|c|}{ Following } & \multicolumn{2}{|c|}{ Running } \\
\hline & & 1 & 2 & 1 & 2 & 1 & 2 & 1 & 2 \\
\hline 158 & 110 & 26 & 60 & 48 & 63 & 44 & 9 & 12 & 40 \\
\hline
\end{tabular}

Data for the analysis were obtained by observations of the animals' behaviour. The observer moved along with the roe-deer and noted on a tape recorder data on the animals' behaviour and the external factors which might have influenced it. One such operation was usually made in one day. In the case of fawns it lasted for the whole of one period of activity (from rising to lying down to rest) and in the case of adult roe-deer for about one hour. A total of 102 such operations, lasting a total of 91 hours 15 minutes, were made with fawns from 14 days to 6 month old. Roe-deer from 7 to 15 month. old were observed for 91 such operations, with a combined time of 71 hours and 55 minutes. Observations made outside such operations were not included in the analysis, that is, when not documented or in doubtful cases. Contacts which had no clear interactional character (e.g. animals approaching each other while feeding) were considered as doubtful.

As can be seen from Table 4, fawns more frequently made touch contact with the keeper during the bottle-feeding period, but older roedeer with other deer. The phenomenon of "following" took a different 
form. Fawns drinking milk preferred to follow another roe-deer than the keeper, while older animals preferred the company of the keeper. The escape reaction appeared in the behaviour of animals about 7 months old and usually was the reaction to the threatening attitude of another animal. As the keeper did not frighten the roe-deer, escape from the keeper expressed the animal's dislike to remaining in his vicinity and was devoid of the element of fear.

In conclusion outstanding proof, even though referring to one case only, of the social tie connecting the roe-deer with their keeper must be given. On 3rd April 1977 during the early morning hours, the unusual behaviour of roe-deer, which were 11 months old at that time, was remarkable: they stood crowded together in the part of the enclosure covered by the old tree stand, and could not be induced to enter the cultivated area. In order to discover the cause of the animals' excitement the keeper began walking right across the cultivated land towards the dense young tree plantation behind it. Halfway over he was alarmed by all the deer barking with a decidedly warning note. It turned out that there was a lynx in the young tree stand, as could be seen from fresh tracks on the remains of snow and still warm faeces. As the roedeer had not withdrawn to the most distant part of the enclosure, it may be concluded that they felt comparatively safe in the old tree stand. The sounds they uttered were thus intended to warn a member of their group of the danger threatening him, to which he was exposed by approaching the young tree stand.

\section{DISCUSSION}

The method here described for preparing a group of roe-deer for field studies has both advantages and disadvantages.

Among its greatest advantages are: (1) The results obtained by this means can be interpolated to wild animals. (2) It ensures a fairly good knowledge of the study animals (their origin, age, sex and individual characteristics). (3) The opportunity for a human to remain in the immediate vicinity of these animals greatly increases the extent of the information obtained. This applies particularly to food relations (Kossak, 1980). By observing all the animals' activities from close up it is possible not only to record which plants or parts of plants are consumed, but also the accompanying circumstances (order in which food is consumed, feeding place, the activities of the other roe-deer during this time etc.). An additional advantage is the opportunity for taking plant samples for further analysis from those on which the roe-deer feed, and to collect data on food rejected by the animals. (4) By habituating the roe-deer 
to their keeper, they become less afraid of other humans, of horse-drawn carts, mechanical vehicles and other manifestations of man's presence. This permits of discovering, when freed from anthropopressure, the daily activity of these animals, together with their preferences for age classes of tree stands and open territory as places for feeding and shelter. During the period when the social tie slackens, the above tolerance does not disappear if the animals are not directly disturbed.

Among the defects of the method affecting the extent of material collected are: (1) Difficulties connected with finding animals living in a large and densely covered area, rendered even greater during the growing season. (2) Difficulty in collecting material in cases of occurrence of territorial behaviour in sexually mature males, and females with young.

The territoriality of bucks, manifested in an aggressive attitude to other members of the group and the keeper, caused (in addition to the considerable difficulties in carrying out observations) disturbances in the animals' behaviour. A tame buck often reacted to the appearance of a human by interrupting the activity in which it was engaged and adopting a group of display and threatening behaviour often ending in attack. Although it was possible, after taking suitable precautions, to carry out observations, the state of emotional excitement of the animal had an adverse effect on the quality of the information obtained. Territoriality in bucks was most clearly manifested from the time the velvet was rubbed off the antlers until the end of the rutting period.

Although the territoriality of a doe with young was not combined with its aggressive attitude to the observer, it greatly hindered, and sometimes made it completely impossible, to carry out observations. The centre of the territory of a doe with young is situated in the place in which the young are present (Kurt, 1968a). Consequently a tame doe, on seeing a human appear near her young, reacted by apparent feeding, during which it moved away from the place where her young were hidden. This action was repeated each time the keeper appeared in her home range. The territoriality of a doe with young appeared as soon as the young were born and decreased in intensity as the fawns grew up. (3) The necessity for employing reliable personnel, distinguished by a high degree of ability to deal with animals, for this kind of work.

It can be seen from the foregoing that the method described for rearing and conditioning a group of roe-deer is by no means a universal and perfect method, nevertheless the information obtained by its use can greatly increase what we know about wild herbivorous animals. 


\section{REFERENCES}

1. Bergerund A. T. \& Nolan M. J., 1970: Food habits hand-reared caribou Rangifer tarandus L. in Newfoundland. Oikos, 21: 348-350.

2. Bubenik A., 1959: Grundlagen der Wildernährung. Deutscher Bauernverlag: 1-299. Berlin.

3. Bubenik A. B., 1965: Beitrag zur Geburtskunde und zu den Mutter-Kind-Beziehungen des Reh (Capreolus capreolus L). und Rotwildes (Cervus elaphus L.). Z. Säugetierkunde, 30, 2: 65-128.

4. Drescher-Kaden U. \& Schulz D., 1973: Die Postnatalentwicklung von Rotund Rehwild bei mutterloser, "künstlicher" Aufzucht. Union Internationale des Biologistes du Gibier. Actes du Xe Congrés, Paris 3-7 mai 1971. Office National de la Chasse: $667-681$. Paris.

4a. Espmark Y., 1969: Mother-young relations and development of behaviour in roe deer (Capreolus capreolus L.). Viltrevy, 6: 461-540.

5. Henning R., 1962a: Über das Revierverhalten der Rehböcke. Z. Jagdwiss, 8: $61-81$.

6. Hennig R., 1962b: Uber einige Verhaltensweisen des Rehwildes (Capreolus capreolus) in freier Wildbahn. Z. Tierpsych., 19, 1: 223-229.

7. Hennig R., 1963: Zur Problematik der forstlichen Rehwildschaden. Waldhyg., 5: $33-49$.

8. Kossak S., 1980: Badania nad sytuacją troficzną saren na siedlisku boru mieszanego w Puszczy Białowieskiej. Ph. D. thesis, Inst. Bad. Leśn. Msc. 1-111. Warszawa.

9. Kurt F., 1968 a: Zusamenhänge zwischen Verhalten und Fortpflanzungsleistung beim Reh (Capreolus capreolus L.). Z. Jagdwiss., 14, 3: 97-106.

10. Kurt F., 1968 b: Sozialverhalten des Rehes (Capreolus capreolus L.). Verlag Paul Parey: 1-102. Hamburg und Berlin.

11. Nagy J. G., 1974: Ermittlung der Nahrungsaufnahme von Wildwiederkäuern durch Beobachtung zahmer Artgenossen. Z. Jagdwiss., 20, 1: 63-67.

12. Pierieldik N., Miłowanow Ł. \& Jerin A., 1975: Żywienie mięsożernych zwierząt futerkowych. Państw. Wyd. Roln. i Leśne: 328-345. Warszawa.

13. Raesfeld F., 1960: Das Rehwild. Verlag Paul Parey: 1-328. Hamburg.

14. Szczerbiński W., 1967: Zagadnienie sarny (Capreolus capreolus). [In: "Kilka zagadnień nowoczesnego łowiectwa"]. Skrypty WSR: 25-84. Poznań.

15. Tschiderer K., 1973: Aufuzcht- Fütterungs- und Hegeversuche beim Rehwild (Capreolus capreolus L.). Z. Jagdwiss., 19, 4: 198-204.

16. Valentincic S., 1975: Das Rehwild und der Wald. Allg. Forstz., 86, 10: 300-302.

Accepted, January 26, 1981.

\section{Simona KOSSAK}

\section{SZTUCZNY WYCHOW I PROWADZENIE GRUPY SAREN Streszczenie}

W pracy opisano metody i przebieg odchowu grupy saren. Koźlęta wykarmiono na butelce mlekiem krowim i zastępczym przygotowanym ze sproszkowanego „dla niemowląt". Ilość wypitego mleka uzależniono od apetytu zwierzęcia (Tabela 2). Acta Theriologica -6 
Łączna ilość dni karmienia wyniosła od 162 do 194. W tym czasie koźlęta wypiły od 128 do 184 litrów mleka/sztukę. Przebieg rozwoju koźląt kontrolowano przy pomocy pomiarów ciężaru ciała i wysokości. Opisaną metodą odchowano 7 koźląt różnej płci.

Stworzenie sarnom odpowiedniego środowiska bytowania jest jednym $\mathrm{z}$ warunków umożliwiających zwierzętom pełne zaspokojenie potrzeb życiowych zarówno fizycznych jak $\mathrm{i}$ psychicznych. $\mathrm{Z}$ tego względu szczególny nacisk położono na właściwe zaprojektowanie i zagospodarowanie zagród hodowlanych. Po okresie odchowu w 0.84 ha, zróżnicowanej siedliskowo zagrodzie, sarny umieszczono na stałe w zagrodzie abejmującej 21,34 ha terenu leśnego. Uznano, że zarówno wielkość zagrody jak i zróżnicowanie drzewostanu (od uprawy poprzez młodnik do starodrzewia) zapewni sarnom odpowiednią bazę żerową w ciągu całego roku, jak i umożliwi im „zagospodarowanie" terenu. W celu uniknięcia stresów wywołanych przegęszczeniem, poprzestano na maksymalnej stawce $6 \mathrm{sztuk/zagrodę.}$

Założeniem podjętych prac było uzyskanie grupy socjalnej, która różniłaby się od występującej w stanie dzikim jedynie tym, iż w jej skład wchodzi człowiek. Aby powstała więź socjalna między sarnami a opiekunem konieczne było: (a) pełne i prawidłowe przebieganie zjawiska imprintingu (Tabela 3) dzięki wczesnemu pozyskaniu koźląt do hodowli (kilka godzin do trzech dni życia), (b) aktywne uczestniczenie opiekuna $\mathrm{w}$ kontaktach o charakterze socjalnym (z wyjątkiem zabaw koźląt). Kontakty te polegają głównie na dotyku, początkowo jednostronnym (opiekun aktywny - koźlę bierne) z upływem czasu nabierającym charakteru wzajemnego (Tabela 3 i 4). Kontakty socjalne pozostają stałym eiementem zachowania się saren po zakończeniu okresu odchowu. Zarówno częste, wielogodzinne przebywanie ze zwierzętami, jak i eliminacja możności emigrowania saren, pozwoliły utrzymać stabilny układ socjalny przez około dwa lata. W późniejszych latach silne rozluźnienie więzi następowało $\mathrm{z}$ samicami prowadzącymi młode i z samcami w okresie rui. Od jesieni do wiosny istniała możliwość ponownego nawiązania kontaktu, lecz polegał on wówczas głównie na tolerowaniu opiekuna w bezpośrednim sąsiedztwie saren.

Przedyskutowano zalety i wady przedstawionej $w$ pracy metody postępowania z grupą saren wraz $\mathrm{z}$ oceną jej przydatności do badań behaviouru jeleniowatych. 